\title{
Key Factors for Development of Export in Polish Food Sector
}

\author{
Irena Łącka', Olga Stefko \\ ${ }^{1}$ Faculty of Economics, West Pomeranian University of Technology in Szczecin, 71-210 Szczecin, 47 Żołnierska St., \\ Poland, irena.lacka@zut.edu.pl \\ ${ }^{2}$ Faculty of Economics and Social Sciences, Poznań University of Life Sciences, 28 Wojska Polskiego St., \\ 60-637 Poznań, Poland, stefko@up.poznan.pl
}

Background: The accession of Poland to the European Union in 2004 facilitated increased exports of food products. It revealed a significant competitive advantage of Polish foreign trade in agri-food products compared to the countries of the »old EU«. After nearly 10 years of Polish membership in the EU, the food sector has still a considerable potential, fostering a further increase in exports.

Objectives: The purpose of the paper was an attempt to establish the current determinants for the possibility to increase the exports of the Polish food sector and to identify potential opportunities and potential threats in the future. It was also decided to give an answer to the question whether any of the group factors has a greater impact on the development of exports than the other, and which issues play only a minor role in the development of international exchange. Method: The analysis used involved the review of the relevant literature and forming a group of experts to specify the key factors of success in the food sector export. Basing on the experts research the STEEPVL analysis was carried out. Results: It turned out that apart from a number of organizational, financial and marketing factors the most important are: the level of the IT infrastructure and the fluctuation of the demand on the international markets for the goods offered by the sector.

Conclusion: Therefore, the focus on the new distribution channels, integrated company management IT systems and changes in the demand on the market is the key challenge for securing the current potential and for the further development of the sector.

Keywords: food sector, exports, key development factors, foresight, STEEPVL method

\section{Introduction}

The contemporary globalized economy, subject to constant changes in all areas of the enterprise surroundings, creates an extremely complex and turbulent business environment. Managers, those of traditional sectors included (ie. in the food sector), are forced to take up economic decisions in the conditions of high uncertainty and risk. Planning for the enterprise future, forecasting future events and needs is very difficult in these conditions. The same problems arise when trying to forecast the future and identify the key factors for the development of the food sector in Poland and its exports.

Using the experience of developed countries, the research on foresight has been conducted for several years in Poland to forecast future events and their effects. Since the 1970s, about 2000 studies of this type have been undertaken so far in the world, and in Poland nearly 40 such projects. The studies were conducted to monitor changes, to foresee and shape the future in relation to regions (regional foresight), industries (industry foresight) or technology (technological foresight), but also to individual companies,

Received: $19^{\text {th }}$ July 2013; revised: $29^{\text {th }}$ November 2013; accepted $15^{\text {th }}$ February 2014 
such as SMEs (the corporate foresight) or to countries (Miles and Keenan, 2002; Dreyer and Stang, 2013). These studies are used in strategic planning at each of these levels (Major and Cordey-Hayes, 2000). The growing interest in these issues is confirmed by topics published in reputed scientific journals, such as »Technological Forecasting and Social Change «, »Futures «, «International Journal of Foresight and Innovation Policy«, »Foresight«, »Technology Analysis and Strategic Management $\ll$.

In the literature, the foresight has been defined as »the systematic, participatory process involving gathering intelligence and building visions for the medium-to-long-term future, and aimed at informing present-day decisions and mobilizing joint actions« (Miles and Keenan, 2002). This process is involved not only in foreseeing the future, but also in its creation. Studies of this type use different research instruments, such as the SWOT method, desk research, STEEPVL $^{1}$ method, brainstorming, building scenarios, the Delphi technique, in-depth interviews, questionnaire surveys and expert panels (Loveridge, 2002; Cairns et al. 2004; Ringland, 2007; Popper, 2008). The basis for all these research tools lies in the cooperation between the partners involved in the process of forecasting and shaping the future. These include representatives of various interest groups such as entrepreneurs, scientists, consumers, administrative staff, consultants and other experts. This makes the foresight a method both active and participatory.

\section{The food sector as a subject of foresight study}

The sector of food and human nutrition has been the subject of foresight studies since the 1990s. As a part of the American project »Food Foresight - Trends Intelligence for Agri-Food Chain« continued since 1993, analyses of trends in the international food trade have been carried out. Development scenarios are created, to be used in the agri-food enterprises and wholesale food distributors (Food Foresight 2011). In the European Union, the issue of the vision for the food industry, agriculture and food markets, in the national and global scale has been the subject of research foresight projects in the UK (Global Food and Farming Futures), the Czech Republic (National Research Programme), France (ie. the foresight for the future of agriculture or the current research on the possibilities for the development of the bio-economy conducted by the French National Institute for Agricultural Research). The results of the foresight projects funded by the EU Framework Programmes (Food, Agricultural and Fisheries 2009) and the work of experts of the European Technology Platform »Food for Life«, made it possible to create scenarios for the agri-food industry in Europe by 2025 (European Technology Platform in 2005; Downey, 2006).

In Poland, attempts to explore the complexity of the subject of food and nutrition were undertaken while working on the Pilot Foresight Project in the Health and Life research field and while implementing some regional projects, such as $»$ Foresight - the prioritary technologies for the sustainable development of the Podkarpacki Region « or »LORIS Vision. Regional technological foresight« (Rogut and Piasecki, 2007; Woźniak ed. 2008). In these studies, the food industry was one of many sectors analyzed in terms of technology and development directions for the regions. These works, however, did not contribute to the creation of a vision for the development of the entire agri-food industry in the country. The research in this field was undertaken only upon the implementation of the project: »Food and nutrition in the twenty-first century - a vision of Polish food sector development « between 2008 and 2012. The food sector was recognized a very important segment of the Polish economy, with a significant share in the value of production sold, gross value added and international exchange.

The Delphi method (was attended by over 300 external experts, representing universities, businesses, institutions, as well as State and local governments) allowed to assess medium-and long-term changes in the market, as well as technological, demographic, social and economic conditions in the sector. The experts have also identified key technologies whose introduction will help to develop and enhance further the competitiveness of Polish industry (Michalczuk, 2011). This comprehensive research work inspired the authoresses to made the further analysis.

\section{The food sector in Poland and its determinants}

The food sector is one of the most important and fastest developing areas of the Polish economy. In 2011, its share in the total sales value of the industry amounted to $22.2 \%$. This value exceeds the average for the European Union, which is $14.5 \%$. Among the states belonging to the European Union, only Denmark and Greece have a higher share than Poland (European industry in a changing... 2009). The following industries have the highest share in the domestic production: meat $(32.9 \%)$, dairy $(18.5 \%)$, fruit and vegetable products (8.4\%) (Statistical Yearbook of Agriculture 2012). The standing of the whole sector, as well as of its leading industries is the result of changes in the agri-food sector started in

1 The name of the research method used was formed from the first letters of the factor group names as follows: Social, Technological, Economic, Environmental, Political factors, those relating to the Value and Legal factors (see Chapter 4, Table 1). 
the 1990s. They had the nature of capital and organizational concentration combined with a modernization of manufacturing processes (Gradziuk, 2009). Another important factor for the growth of the food sector performance in the last decade was the accession of Poland to the European Union on 1st May 2004. This event triggered further structural, modernization and investment changes.

These changes have led to the approximation of the structure and competitiveness of the Polish food industry to that of developed countries. This had a favourable effect on the international trade in this sector. The integration of Poland with the EU allowed to make clear the advantages of this country in the agri-food products foreign trade. It contributed to a rapid growth of the food industry exports and improved the balance of foreign trade (Rytko, 2005; Pawlak, 2007; Urban et al. 2010; Kowalski et al. 2012). The most competitive industries of the Polish food sector include: meat, dairy, fruit-and-vegetable, confectionery products, cereals secondary processing and tobacco products manufacturing.

Since the accession of Poland to the EU, the volume and value of agri-food products exports has been steadily increasing. The Polish food sector has un-uniform trade relations, ie the dominant partners in this exchange are the EU Member States (Production and trade in... 2013). The trade turnovers in agri-food products with these countries have kept increasing after the accession of Poland to the EU much faster than with third countries and contributed to the ever-growing positive trade exchange balance. In 2012, the value of food exports amounted to EUR 15.2 billion, which accounted for $10.6 \%$ of total exports. The turnover balance was positive and amounted to EUR 2.6 billion. As to the total balance of the Polish agri-food trade with nonEU members, it has been negative for years (Foreign Trade Statistical Yearbook 2013).

In the first years after the integration, Polish entrepreneurs exploited primarily competitive advantages based on lower labour and raw materials costs and lower margins of processing, but over the years, some of producers changed their competitive strategies. Leaders of industries include in the other sources of competitiveness: the quality and uniqueness of products, the ability to identify and meet the individual demands of customers, comprehensive promotional activities, as well as the creation of the company's image based on the confidence in the quality and the reliability of products and high quality customer service. The innovativeness, entrepreneurship, knowledge and intellectual capital are also considered important. New competitiveness strategies prepare companies to inevitable changes in the environment, the impact of current economic factors and the trend of globalization (Kowalski et al. 2012). Since 2011, a decreasing domestic demand has been observed together with escalating market restrictions, rising raw material prices, prices relations unfavourable for processors, high changeability and declining production dynamics, as well as an instability of financial results, slowing down processes of concentration and increasing external constraints. These conditions are forcing the sector enterprises to continue the process of business improvement and to enhance its efficiency.

The long-term planning of the company's development requires a monitoring of trends in the wider environment, not only in the nearest neighbourhood, but also in very distant countries. Entrepreneurs must be able to respond to the extent possible to changes in the demand for their products not only in the domestic market but also in the world. They are to notice export opportunities in the markets hitherto completely overlooked. The market opportunities create new products even such ones that formerly were treated as food products of little value. Yet, in other parts of the world they can be considered a delicacy. A very important factor to determine the presence of Polish products in the foreign markets is the reputation of Poland as a food producer. It depends on the observance of quality standards and food (veterinary, sanitary, commercial quality, et al.) safety.

\section{Methodology}

The most important research task of this study was to determine the key factors for the exports development of Polish food products, using the STEEPVL method. To implement the main purpose of the study, both primary and secondary materials were used. To evaluate the factors, influencing the development of the Polish food sector international exchange, an analysis of the literature dedicated to this topic was carried out. Based on the desk research and the secondary data (official statistics) the Polish food sector was presented and its hitherto conditions of development. Particularly highlighted were the achievements of the Polish food producers in the exports of agri-food products, mainly to the EU markets. The growing importance of the economic situation and the globalization for the possibility of development of the sector and its exports was pointed out. Then, the above analysis allowed to identify and determine the strength of the factors, influencing the development of the international trade (exports) of this sector, with the use of the STEEPVL method.

The analysis was made in the following stages:

- team of 11 experts was conducted. It consisted of scientists, entrepreneurs engaged in the production and trading in food products and consumers. The group of experts was chosen deliberately, according to the following criteria: knowledge of issues related to exports and imports of food products, direct or indirect participation in the international exchange processes of food products, their consent to participate in the study.

- according to literature (Mendonca et al. 2004; Ringland, 2007; Sutherland and Conwell, 2007) the 6 areas of the 
main factors affecting the development of the test area were defined (i.e. Social, Technological, Economic, Environmental, Political Value and Legal),

- the group of experts were asked to write maximum number of factors within 6 areas, affecting the change in the volume of international trade in food products (by brainstorming),

- then, the factors of main 6 groups were reduced to 3 (display method - each of the expert participating in the study chose three factors which he/she considers the most

Table 1: The choice of the main factors in the different areas of STEEPVL analysis

\begin{tabular}{|c|c|}
\hline Factors designation & Type of STEEPVL factors \\
\hline \multicolumn{2}{|l|}{ Social (S) } \\
\hline S1 & $\begin{array}{l}\text { Level of public confidence in food products (loss of confidence following such } \\
\text { events as: salt scandal, horse meat scandal etc.) }\end{array}$ \\
\hline S2 & $\begin{array}{l}\text { Human resources potential (a team of people to ensure smooth contacts with foreign } \\
\text { partners) }\end{array}$ \\
\hline S3 & High quality assessment and tastiness of Polish food \\
\hline \multicolumn{2}{|l|}{ Technological (T) } \\
\hline $\mathrm{T} 1$ & $\begin{array}{l}\text { Technical and technological equipment, ensuring the standards of food quality and } \\
\text { safety required abroad }\end{array}$ \\
\hline $\mathrm{T} 2$ & $\begin{array}{l}\text { IT infrastructure development level (Access to novelties via the Internet, trade devel- } \\
\text { opment - new distribution channels, integrated informative systems to manage the } \\
\text { company) }\end{array}$ \\
\hline T3 & $\begin{array}{l}\text { Level of technological advancement of enterprises while using new technologies } \\
\text { (new lines, new technological solutions) }\end{array}$ \\
\hline \multicolumn{2}{|l|}{ Economic (Ecn) } \\
\hline Ecn1 & Fluctuation in the demand for goods offered by industry in international markets \\
\hline Ecn2 & Price and cost competitiveness of Polish food products in foreign markets \\
\hline Ecn3 & Improvement in the management of production process \\
\hline \multicolumn{2}{|l|}{ Enviromental (Env) } \\
\hline Env1 & Ecological and healthy food \\
\hline Env2 & Development barriers connected with environmental protection \\
\hline Env3 & Environmental organizations activities \\
\hline \multicolumn{2}{|l|}{ Political (PI) } \\
\hline P11 & Promotion of Polish brands in the world \\
\hline $\mathrm{P} 12$ & Support to exports of food products \\
\hline $\mathrm{Pl} 3$ & $\begin{array}{l}\text { Introduction of restrictions on imports of food from defined states ( because of } \\
\text { threats or poor quality) }\end{array}$ \\
\hline \multicolumn{2}{|l|}{ Value (V) } \\
\hline $\mathrm{V} 1$ & Level of readiness to co-operate \\
\hline $\mathrm{V} 2$ & Need of innovativeness \\
\hline V3 & Need of creativity \\
\hline \multicolumn{2}{|l|}{ Legal (L) } \\
\hline L1 & Predictability of fiscal system \\
\hline $\mathrm{L} 2$ & Legal support to exports processes (transport, contracts, claims, warranties) \\
\hline L3 & Degree of red tape and regulations \\
\hline
\end{tabular}


important). In this phase, all 21 factors in separate 6 areas have the same importance for all experts (see table 1),

- then, the isolated groups of factors were evaluated in terms of the strength of the impact on the increased export. A 7-step Likert rating scale was used where $» 1 \ll$ indicates factors of very little importance or unimportant, but $» 7 \ll$ means very important factors for the achievement of the objective. The numbers between 1 and 7 described the increase in the importance of the particular factor. All the results obtained from the experts were summed up for the specific columns (using weights from 1 to 7). Afterwards, the sums of the answers (indications) were multiplied by the weights giving the ranking of the specific factors,

- in the next step was evaluation of uncertainty defined factors. The Likert 7-point scale rating was also applied. This time, however, rating » 1 « was assigned to the indicators labelled as very little predictable, while rating $» 7 \ll-$ to very predictable. The experts taking part in the study were asked the question about the predictability of the factors, because according to Loveridge (2002) it appeared to be more relevant than the question on uncertainty. Then, the rating scale was converted as follows: $(1 \rightarrow 7)(2 \rightarrow 6)(3$ $\rightarrow 5)(4 \rightarrow 4)(5 \rightarrow 3)(6 \rightarrow 2)(7 \rightarrow 1)$.
Research was carried out from April to July 2013 amongst the experts, regarding the multi-faceted and multidimensional determinants for the development of the exports of Polish food products. When formulating the results, the quantitative and qualitative methods were applied. Based on Postma and Liebl (2005), Steinert (2009) and Godet et al. (2006) to analyze the collected material, the method of Key Success Factors was used. Owing thereto, the most important factors, the conditions to acquire the competitive advantages, were determined.

This allowed for the final inference to give the key factors, contributing to changes in the volumes of Polish food products exports.

\section{Results and Discussion}

The development and evolution of export destinations in enterprises belonging to the Polish food industry, as well as the determinants of these changes depend on many factors that are often in the surroundings of a given organization. In the opinion of the experts involved in the study, the value of the foreign turnover in the sector products does not depend so much upon the economic situation, or the rates

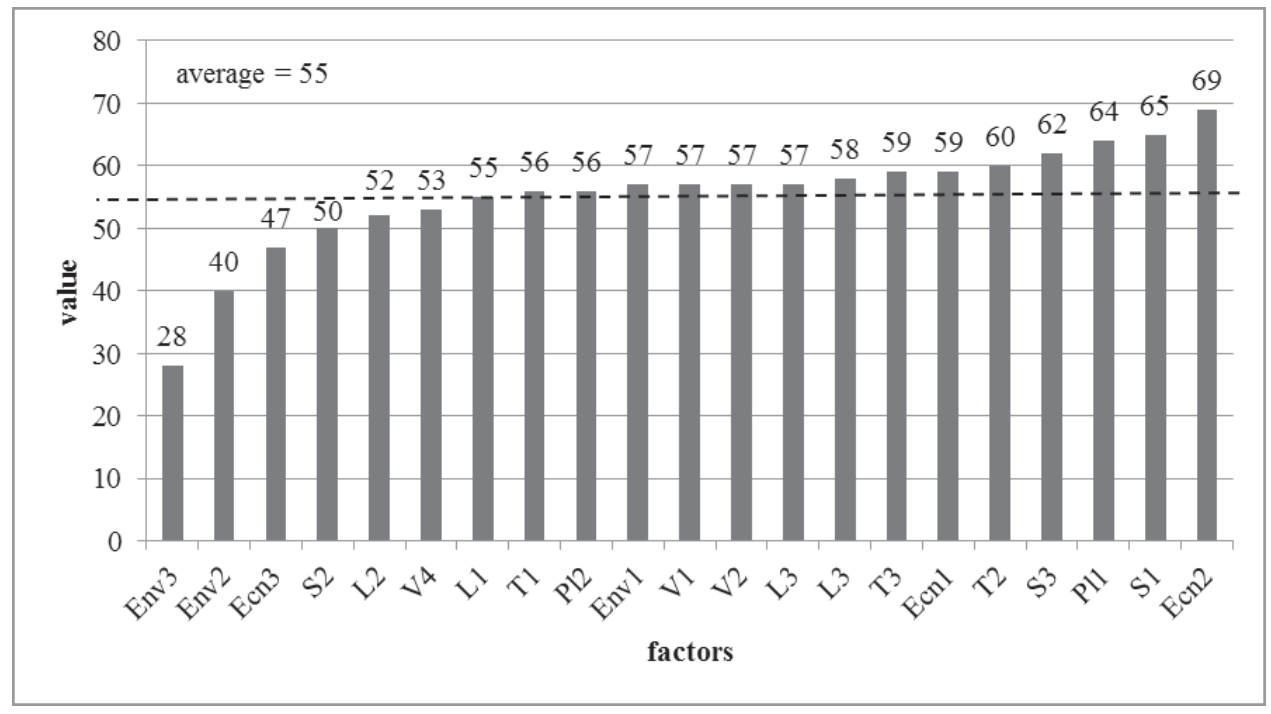

Example for calculation in factor Ecn 2-Price-and-cost competitiveness of food products in foreign markets:

$\left(1^{*} \cdot 0 * *\right)+(2 * \cdot 0 * *)+\left(3 * \cdot 0^{* *}\right)+\left(4 * \cdot 1^{* *}\right)+\left(5^{*} \cdot 1^{* *}\right)+\left(6^{*} \cdot 3^{* *}\right)+\left(7 * \cdot 6^{* *}\right)=69 * * *$

$*$ the weights - from the least important to the most important

** the accumulated number of the answers given by the experts

*** the final ranking for the specific factor

Figure 1. Factors determining the development of international trade 
of foreign exchange, but on public fear publicized by the mass media which concerns various aspects of unpleasant consequences of eating certain foods (bird flu, mad cow disease, foot and mouth disease, genetically modified food). During the discussion, the experts invited to participate in the study also raised numerous examples of activities in the so-called gray zone, and the failure to comply with the rules of good conduct in business (some companies never subject their marketed products to immunochemical testing so as to reduce costs). They also discussed the problems with financial liquidity and with the regularity of supplies of high quality raw materials for the production. Some speakers mentioned the recent activity of transnational corporations and progressive structural changes in the sector (vertical and horizontal concentration, consolidation, integration).

Hence, starting the main purpose, which was an attempt to select factors determining the development of food enterprises exports, in the first place, it was decided to isolate groups of the so-called Key Success Factors (see Table 1).

Then the strength of their impact on the increased export capacity of the food industry enterprises were evaluated, which is presented in Figure 1. It turned out that the most important factor for the development of enterprises exports is one from the economic group, marked as Ecn2 »Price and cost competitiveness of Polish food products in foreign markets« (Figure 1). Social issues were slightly less important, but located on the second place amongst the obtained results of analysis. At the same time, the S1 factor, »The level of public confidence in food products« was pointed out. On the third place, with only slightly fewer points, the Pl1 political factor, »Promotion of Polish brands in the world « was found. The Ecn3, »Improvement in the management of the production process « proved to be the least important in the economic group.

In the further part of the analysis, assessing the degree of predictability of the future state of the determinants which make the conditions for the growth of export were also ranked. A list of factors diversified in terms of uncertainties was obtained (Fig. 2).

Most concerns were raised by environmental issues, mainly by Env3 »Environmental organizations activities« and Env2 »Development barriers connected with environmental protection«. Slightly fewer points on a scale measuring the uncertainty factors were given to: Technological T3 $»$ Level of technological advancement of enterprises while using new technologies (new lines, new technological solutions)«, and economic Ecn3 »Improvement in the management of production process «. In the case of the social factor labelled S3 »High quality assessment and tastiness of Polish food « the least risk for the development of export opportunities of Polish food producers was perceived. In this group, it received the least significant number of points.

The results of the analysis related to the uncertainty in combination with the assessment of the factors, affecting the opportunity to increase the exports of food industry enterprises were the basis for an initial separation of factors, making up the conditions for the task implementation (Fig. 3). Based on the data presented in Figure 3, the factors

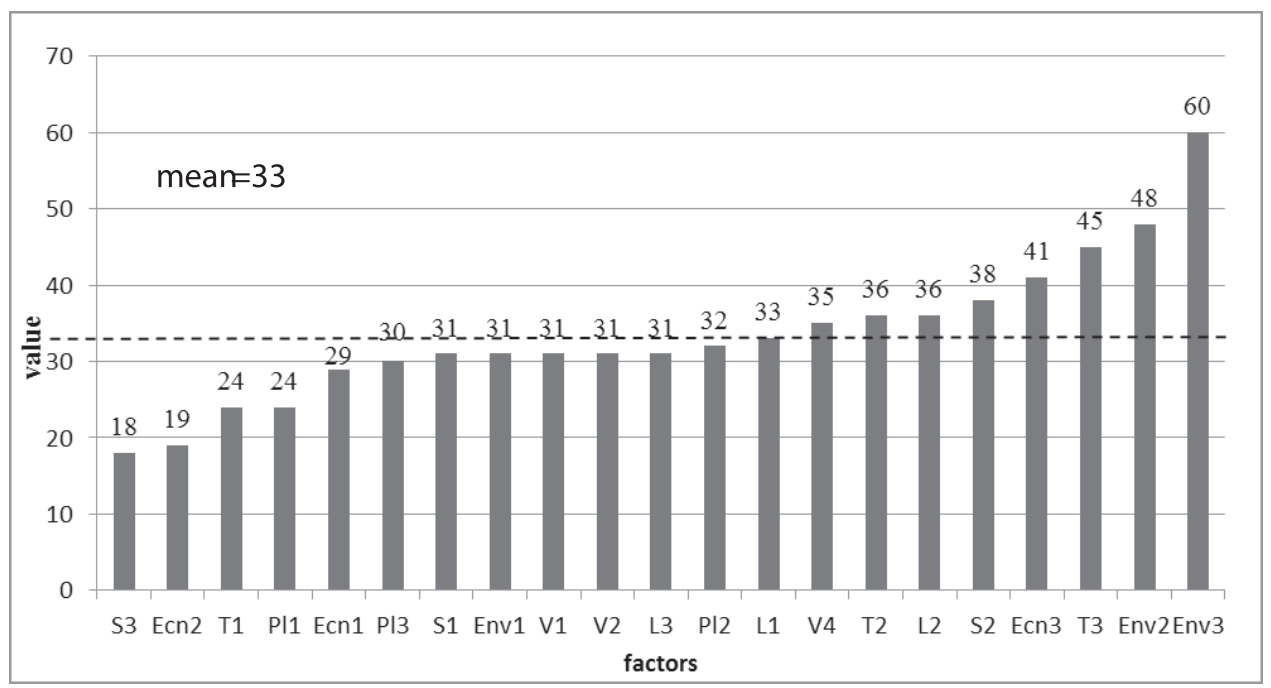

Example for calculation in factor Env 3: Activity of environmental organizations $(1 \cdot 1)+(2 \cdot 1)+(3 \cdot 2)$ $+(4 \cdot 2)+(5 \cdot 1)+(6 \cdot 3)+(7 \cdot 1)=60$

Figure 2. Evaluation of uncertainty factors associated with the development of international trade 


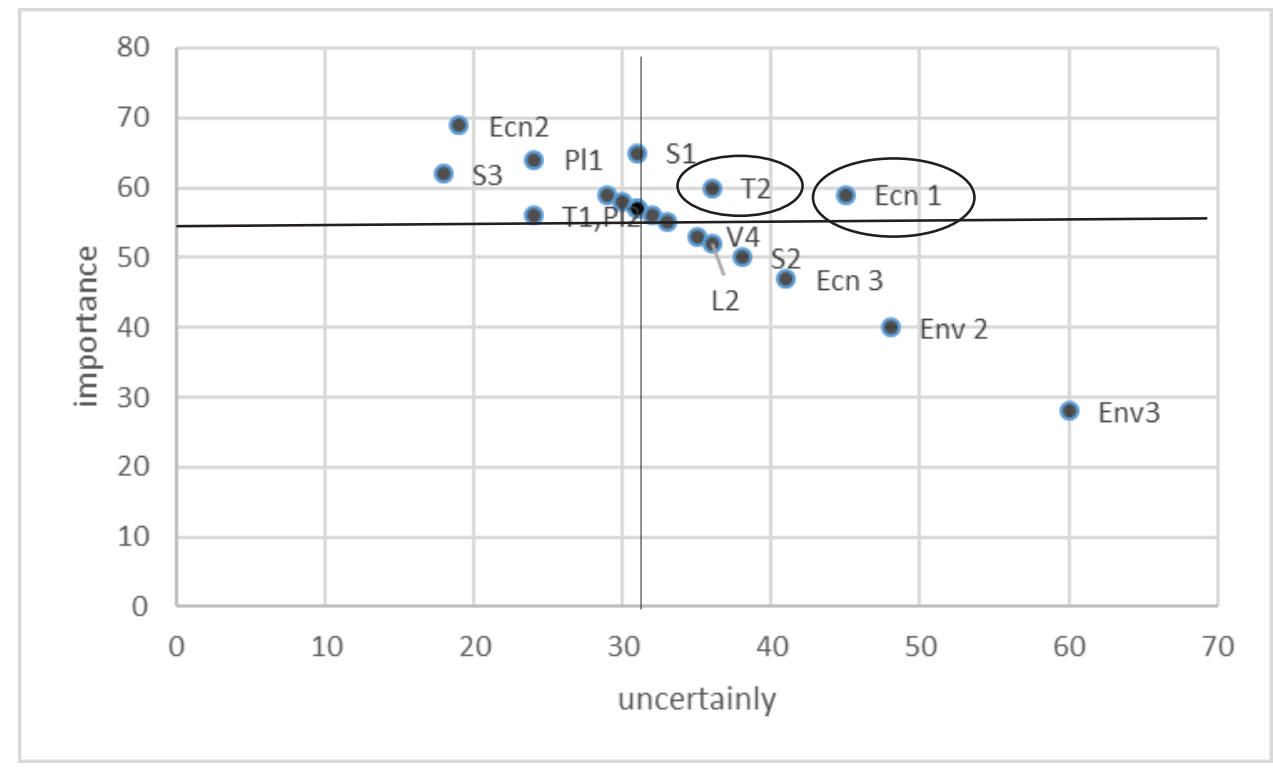

Figure 3. Factors crucial to the development of the international trade

included in the technological group T2 $\gg \mathrm{IT}$ infrastructure development level (Access to novelties via the Internet, trade development - new distribution channels, integrated informative systems to manage the company)« and economic Ecn1 »Fluctuation in the demand for the goods offered by industry in international markets « were considered as such.

At the same time, both of the above-mentioned factors were characterized by a higher assessment of uncertainty than the average for the entire group of 33 and a higher evaluation of validity than the average of 55 recorded there. It is surprising that the environmental issues concerns which give rise to worst fears (when measuring uncertainty) do not have key importance in the final chart.

The Ecn2 »Price and cost competitiveness of Polish food products in foreign markets « are similarly assessed just as the $\mathrm{S} 1$ issues of public confidence associated with a number of recent food scandals, which were pointed out as the most crucial for the prospects of the food sector exports in Poland. The analysis shows that in the future, it is necessary to focus not on technical and technological innovations, but rather on the knowledge and information, resulting from a continuous monitoring of changes in the sector surroundings and the level of customer satisfaction measured by the degree of meeting their demands.

\section{Conclusions}

The food sector as the one of the most important and the fastest developing areas of the Polish economy has been drawing attention of numerous experts for years. According to the previous analyses (e.g. Rytko, 2005; Pawlak, 2007; Urban et al. 2010; Kowalski et al. 2012) it has considerable export opportunities.

It has been shown that many of competitive advantages have become apparent after the accession of Poland to the EU. These included, among others: lower costs of labor and raw materials and processing margins. With the time, after a change in the market situation, the quality and uniqueness of products were focused on, together with the ability to identify and meet the individual needs of buyers, the comprehensive promotional activities and the creation of the company image based on the confidence in quality and reliability of products and in high quality of customer service.

Based on the STEEPVL analysis it was decided that:

- Most concerns were related to environmental issues, mainly to the activities of environmental organizations and the environmental protection.

- Experts were slightly less worried by the technological level of enterprises advancement in the use of new technologies, understood as the introduction of new lines and technological solutions and changes, regarding the need to improve the management of the production process.

- However, from all these elements, either supporting the development of the agri-food industry or threatening it, mainly two stand out in the foreground: the IT infrastructure development level (Access to novelties via the Internet, trade development - new distribution channels, integrated informative systems to manage the company) and the fluctuation in the demand for the goods offered by the industry in the international markets. 
- The focus on these two areas should benefit both Polish enterprises and the entire sector concerned in trading in the food products in the international markets.

- It is necessary to deepen further the analyses of the factors, determining the possibilities to increase the exports of Polish food products.

The determinants for the development of foreign trade in Polish food products, determined in the desk research, were confirmed by the list of key factors, influencing the export sector, established by the experts and other participants in the STEEPVL study. The studies lead to the conclusion that the Polish food industry operators should take advantage of price and cost competitiveness of Polish products in the foreign markets and the high assessment of the quality and flavor of these products combined with the public confidence in Polish products. However, let us not forget of price-cost competitive advantages being reduced and the need for Polish producers to search new opportunities to increase exports with the use of, inter alia, innovative products (that better meet the needs of buyers), to improve production efficiency, to try to achieve the highest possible quality and food safety. This will allow maintaining a favorable opinion on the Polish food products domestically and abroad. It is also necessary to search for new markets (outside Western Europe), which will ensure the decrease in the dependence of Polish food sector on the EU market and the consequent vulnerability to the economic situation, fluctuations in currency and demand in the European and Polish food markets. To achieve this goal, not only the activity of the Polish food producers seems necessary to acquire new customers in the global market and to compete with transnational corporations, but also the involvement of the State in assisting to promote Polish products and brands in foreign markets. Another factor to help to increase the opportunities for the international exchange sector development should be better endeavors of the State to ensure that the principles of fair competition and integrity in business and while food producing are met by Polish producers, in accordance with the requirements for food products quality and safety.

\section{References}

Cairns, G., Wright, G., Bradfield, R., van der Heijden, K., \& Burt, G. (2004). Exploring e-government futures through the application of scenario planning. Technological Forecasting and Social Change, 71: 217-238, http://dx.doi.org/10.1016/ S0040-1625(02)00371-2

Downey, L. (2006). Agri-Food Industries \& Rural Economies by 2025. Towards a Knowledge Bio- Economy - Research \& Knowledge Transfer Systems. School of Agriculture, Food Science \& Veterinary Medicine, University College Dublin \& Biology Department, National University of Ireland, Maynooth, Retrieved November 20, 2013, from http:// ec.europa.eu/research/agriculture/scar/pdf/scar_foresight_ rural_economy_en.pdf
Dreyer, I., \& Stang, G. (2013). Foresight in Governments - practices and trends around the world, in: EU ISS Yearbook of European Security YES 2013. Paris: European Union Institute for Security Studies.

European industry in a changing world updated sectoral overview 2009 (2009). Brussels: Commission of the European Communities

European Technology Platform Food for Life. The vision for 2020 and Beyond (2005). Brussels. Retrieved January 21, 2013, from https://www.wko.at/Content.Node/branchen/w/Nahrungs--undGenussmittelindustrie--Lebensmittelindustrie-/Broschuere European_Technology_Platform.pdf

Food, Agriculture and Fisheries, 2009. 2nd SCAR Foresight Exercise. New Challenges for Agricultural Research: Climate Changes, Food Security, Rural Development, Agricultural Knowledge System. (2009). Luxembourg: Directorate General for Research - Office for Official Publications of the European Communities.

Food Foresight. 2011 Trends Intelligence for the Agrifood Chain (2011). Retrieved December 2, 2013, from http://www.beefboard.org/news/files/News feed/ Food\%2520Foresight $\% 2520$ August $\% 25202011$ Final2.pdf

Godet, M., Durance, P. \& Gerber, A. (2006). Strategic Foresight. La prospective. Problems and methods, The LIPSOR Working Papers 20, Gerpa: Laboratoire d'Investigation en Prospective, Stratégie et Organisation. Retrieved September 11, 2013, from http://www.laprospective.fr/dyn/francais/memoire/strategicforesight.pdf

Gradziuk, K. (2009). Development of food industry in Poland in the years 1998-2007. Scientific Papers of the Warsaw Agricultural University. Problems of Agriculture of the World, 6 (21): 41-50.

Kowalski, A., Wigier, M., \& Dudek, M. (2012). Competitiveness of food economy in the conditions of globalization and European integration, Multi-Annual Programme 2011-2014, Competitiveness of the Polish economy under the conditions of globalization and European integration, no. 60. Warsaw Institute of Agricultural and Food Economics - National Research Institute.

Loveridge, D. (2002). The STEEPV acronym and process - a clarification. Ideas in Progress 29, The University of Manchester, PREST.

Major, E.J., \& Cordey-Hayes, M. (2000). Engaging the business support networks to give SMEs the benefit of foresight, Technovation 20: 589-602, http://dx.doi.org/10.1016/S01664972(00)00006-7

Mendonca, S., Cuhna, M.P., Kaivo-oja, J. \& Ruff, F. (2004). Wild cards, weak signals and organizational improvisation, Futures 36, 201-217, http://dx.doi.org/10.1016/S00163287(03)00148-4

Michalczuk, L. (ed.). (2011). Żywność i żywienie w XXI wieku Scenariusze rozwoju polskiego sektora rolno-spożywczego. [Food and nutrition in the twenty-first century - Scenarios of Polish Agri-food Sector] Łódź: Społeczna Wyższa Szkoła Przedsiębiorczości i Zarządzania in Łódź.

Miles, I., \& Keenan, M. (2002). Practical Guide to Regional Foresight in the United Kingdom. Brussels: PREST, University of Manchester, European Commission.

Pawlak, K. (2007). Changes in Polish foreign trade in agri-food products under accession to the European Union. Annals of Agricultural University of Poznań. Economics 6: 97-107. 
Popper, R. (2008). Methodology, in: Georghiou, L., Harper, J.C. \& Keenan, M., The handbook of technology foresight. Concepts and practice, Cheltenham: Elgar.

Postma, T.J.B.M., \& Liebl, F. (2005). How to improve scenario analysis as a strategic management tool? Technological Forecasting and Social Change, 72 (2): 164, http://dx.doi. org/10.1016/j.techfore.2003.11.005

Production and foreign trade in agricultural products in 2012 (2013). Warsaw: Central Statistical Office.

Ringland, G. (2007). Technology Foresight for Practitioners. A Specialized Course on Scenario Building, Prague: UNIDO.

Statistical Yearbook of Foreign Trade in 2013. (2013). Warsaw: Central Statistical Office.

Statistical Yearbook of Agriculture 2012 (2012). Warsaw: Central Statistical Office.

Rogut, A., \& Piasecki, B. (ed.) (2007). LORIS wizja. Regionalny foresight technologiczny, [LORIS vision. Regional technological foresight] Łódź: College of Social Publishing School of Management in Łódź.

Rytko, A. (2005). Analysis of trade relation between Poland and the European Union and their impact on volume and structure of agri-food articles' trade. Electronic Journal of Polish Agricultural Universities, 8 (4). Retrieved June 30, 2013, from http://www.ejpau.media.pl/economics/volume8/issue4/ index.html

Steinert, M. (2009). A dissensus based online Delphi approach: An explorative research tool. Technological Forecasting and Social Change, 76: 291-300, http://dx.doi.org/10.1016/j.techfore.2008.10.006

Sutherland, J., \& Canwell, D. (2004), Key concepts in strategic management. Basingstoke: Palgrave MacMillan.

Urban, R. Szczepaniak, I. \& Mroczek, R. (2010). The Polish food sector in the first years of membership (Synthesis), MultiAnnual Programme 2005-2009. The economic and social conditions of the development of the Polish food economy following Poland's accession to the European Union, no. 177.1, Warsaw: Institute of Agricultural and Food Economics - National Research Institute.

Woźniak, L. (ed.) (2008). Końcowy raport z badań: Foresight. Priorytetowe technologie dla zrównoważonego rozwoju województwa podkarpackiego. [Final research report: Foresight. Priority technologies for sustainable development of the Podkarpacki Region]. Rzeszów: Oficyna Wydawnicza Politechniki Rzeszowskiej.

Irena kącka is an associate professor of economics at the West Pomeranian University of Technology in Szczecin. She works at the Faculty of Economics. Łącka has received Ph. D. in economics from Warsaw University of Life Science, on the Faculty of Economic Sciences. Her research interests are: strategic alliances, food industry, cooperation of scientific and research institution with enterprises, linkages science-industry, innovativeness and competitiveness of economy, knowledge based economy.

Olga Stefko has Ph.D. in economics and organization of food industry within agricultural sciences. She is a professor assistant at the Faculty of Economics and Social Sciences, Poznań University of Life Science in Poland. Her main research interests include economics, finance and capital in horticulture production. Recently, she has been focusing on food industry enterprises, their innovations in development and competitiveness using one of the methods included in the foresight - STEEPVL analysis. The comparative analysis is carried out both on domestic and foreign markets. 